\title{
Environmental Regulation, Solar Energy Technology Components and International Trade \\ - An Empirical Analysis of Structure and Drivers
}

\author{
Felix Groba ${ }^{1, *}$ \\ ${ }^{1}$ German Institute of Economic Research, Berlin, Germany \\ * Corresponding author. Tel: +49 30 89789681, Fax: +49 30 89789113,E-mail: F.Groba@diw.de
}

\begin{abstract}
Dynamics of the global renewable energy market are mostly described in terms of investment and added capacity. The role and characteristics of cross border trade flows with renewable energy system components, however, remains blurred. While national environmental regulation and innovative capacity is important for the promotion of renewable energies the effect of regulation and innovative efforts on export dynamics remains ambiguous as empirical studies on the pollution haven and the Porter hypothesis reach diverging conclusions and rarely focus on the renewable energy sector. This paper closes the gap by: First, focusing on solar energy technology components, structure and development of international trade since 1996 is analyzed. Second, determinants of OECD exports are identified in an econometric panel study estimating a gravity trade model. The results unveil a highly dynamic global market for solar energy technology components since 2002, with Europe as dominant market and increasingly strong exports from China. Additionally, the analysis supports the Porter hypothesis as countries with a strong framework supporting renewable energies have gained a comparative advantage in exporting solar technology goods. Analyzing the importer side shows that tariff reduction and FDI inflows have increased imports.
\end{abstract}

Keywords: Renewable Energies, International Trade, Trade Barriers, Regulation

\section{Introduction}

Diffusion and transfer of climate friendly energy technologies remain decisive topics in international climate negotiations as they play an important role in the nexus of economic development and a sustainable energy system transformation. Therefore, the development of the global renewable energy market is monitored in numerous studies. These studies commonly either refer to added capacity or investments into renewable energy projects to describe growth, structure and market development [1]. Although international trade has been identified as a decisive channel for technological change the role of the manufacturing sector, producing necessary components, and the international trade system in this production process is mostly neglected. While the interaction between trade flows and environmental regulation and the issue of clean technology transfer have become prominent literature strands, little effort has been put into accessing drivers and dynamics of global trade with specific renewable energy components. Additionally, current negotiation obstacles in WTO talks on environmental goods liberalization unveil that the relationship between trade, technology transfer and clean energy technologies are relevant.

The objective of this paper is to analyze the structure and identify drivers of clean energy technology trade with a specific focus on solar energy technology components. This step is necessary before trade effects such as technology diffusion and sustainable development can be studied in later research. After outlining the methodology, this paper describes structure and development of the international market for solar energy technology components. Subsequently, potential drivers of these specific technology exports from OECD countries to the world are characterized in a panel study estimating a standard gravity model. Three hypotheses are empirically tested: First, as components for solar energy systems are research intensive, the innovative capacity in exporting countries affects the export performance with respective goods. Second, following the Porter hypothesis, countries with a strong policy 
framework of supporting renewable energies have gained a comparative world market advantage as such a framework is likely to support a national renewable energy industry that is a striving for export markets. Third, barriers to trade and an unreliable policy environment in receiving countries are obstacles to clean technology trade as additional costs to exporters are imposed.

\section{Data description and methodology}

Numerous empirical studies adopted the gravity model to explain the relationship between international trade flows and environmental regulation with respect to various goods and sectors. Introduced by Tinbergen [2] the model became the workhorse of trade relation analysis. The popularity can be explained by its successful empirical performance and by strong theoretical foundations outlined in the literature [3]. The general formulation of the gravity model (1) describes trade flows $(F)$ from exporting country $i$ to destination country $j$ at time $t$ as a function of economic masses $(M)$, distances $(D)$ and an error term $(\eta)$. It furthermore takes a gravitational constant $(G)$ into account depending on the units of measurement for $F_{i j t}, M_{i t, j t}$.

(1) $\quad F_{i j t}=G \frac{M_{i t}^{\beta_{1}} M_{j t}^{\beta_{2}}}{D_{i j}^{\beta_{3}} \eta_{i j t}}$

As the aim of the study is to determine the drivers of international trade with solar energy technologies, the dependent panel variable is the bilateral export flow $\left(E X P_{i j t}\right)$ from $i$ to $j$ at time $t$. The $i$-exporting countries are Australia, Austria, Belgium, Canada, Czech Republic, Denmark, Finland, France, Germany, Greece, Ireland, Italy, Japan, Korea, Netherlands, Norway, Portugal, Spain, Sweden, Switzerland, the United Kingdom and the United States. An analysis of developing country exports such as Chinese exports is excluded due to a lack of data on c ontrol variables. Nevertheless, the sample represents approximately $80 \%$ of global exports in 2008. The sample of $j$-importing countries includes 129 states, including OECD countries. The time period analyzed with the balanced panel goes from 2000 to 2007 . Empirical computation requires the gravity model to be transformed into logs, establishing a linear relationship between variables. This also allows interpreting the percentage change in the dependent variable due to a change in explanatory variables. Based on the explanatory variables, as explained in the subsequent sections, the exact gravity model applied has the following from:

$$
\begin{aligned}
\ln \text { SolarEXP }_{i j t}= & \beta_{0}+\beta_{1} \ln \left(\text { GDP }_{i t} \text { GDP }_{j t}\right)+\beta_{2} \ln \left(\text { POP }_{i t}\right)+\beta_{3} \ln \left(\text { POP }_{j t}\right)+\beta_{4} \ln \left(\text { Dist }_{i j}\right) \\
& +\beta_{5} \text { Border }_{i j}+\beta_{6} \text { Language }_{i j}+\beta_{7} \text { Contig }_{i j}+\beta_{8} \text { Import__ariff }_{j i t} \\
& +\beta_{9} \ln \left(\text { FDI }_{j t}\right)+\beta_{10} \text { RoL }_{j t}+\beta_{11} \ln \left(\text { Envirregulation }_{j t}\right) \\
& +\beta_{12} \ln \left(\text { EnergyIntensity }_{i t}\right)+\beta_{13} \ln \left(\text { Envirregulation }_{j t}\right)+\beta_{14} \ln \left(\text { RDBSolar }_{i t-1}\right) \\
& +\beta_{15} \ln \left(\text { PatentStock }_{i t}\right)+\alpha_{i}+\varepsilon_{i j t}
\end{aligned}
$$

\subsubsection{Development of solar energy technology component exports}

Solar energy technology components are defined as investment goods and associated products needed in solar energy systems. This includes solar thermal and photovoltaic components. Reliable cross country data on trade flows with renewable energies are hardly available. National industry polls, commonly asking for sales as well as imports and exports, are likely to be biased as the number of companies active in the renewable energy market is unclear and poll return might be interest driven. Therefore, the representativeness of these polls is limited and can only be used as a rough indicator for national branch development. Furthermore, 
industry polls do not guarantee data comparability. Therefore, international trade data based on the Harmonized Commodity Description and Coding Systems (HS 1996) using the UNCTAD COMTRADE database serves as the source of the dependent variable.

The classification with respect to environmental goods and energy technologies has been well defined by the OECD [4]. Nevertheless, the aspired solar energy technology differentiation requires addressing data validity. A product group based on 6 -digit HS 1996 codes, under which solar system components are traded, has been generated (Table 1). The problem is that data might be inflated as the products environmental end use cannot be monitored, i.e. goods that are used for renewable energy systems and goods that might be used otherwise are traded under a common HS code and the renewable energy goods share under one HS code might vary between countries. However, the method used constructs the best available proxy for cross time cross country analysis as data is available on an international common methodology. Furthermore, contrary to industry polls, imports of inputs are likely to be captured allowing a more comprehensive picture of the market. Finally, product similarity can be assumed making the actual end use irrelevant.

Table 1. Nomenclature of solar energy technologies, HS 1996.

\begin{tabular}{ll}
\hline HS Code & Explanation \\
Solar Thermal \\
841911 & $\begin{array}{l}\text { Instantaneous gas water heaters. } \\
841919\end{array}$ \\
$\begin{array}{l}\text { Other instantaneous or storage water heaters, non-electric. } \\
\text { S40219(ex) }\end{array}$ & $\begin{array}{l}\text { Steam or other vapor generating boilers [Other vapor generating boilers, } \\
\text { including hybrid boilers] }\end{array}$ \\
$841950(\mathrm{ex})$ & $\begin{array}{l}\text { Heat exchange units [Heat-exchange units for solar thermal or geothermal } \\
\text { applications]. }\end{array}$ \\
900290 & $\begin{array}{l}\text { Concentrator systems to intensify solar power in solar energy systems, other } \\
\text { optical elements of any material mounted }\end{array}$ \\
Solar Photovoltaic \\
$850440(\mathrm{ex})$ & $\begin{array}{l}\text { Static converters [Inverters (for converting DC power to AC power)] - change } \\
\text { solar energy into electricity. }\end{array}$ \\
$850720(\mathrm{ex})$ & $\begin{array}{l}\text { Other lead-acid accumulators [solar batteries], i.e batteries for energy storage } \\
\text { in off-grid photovoltaic systems. }\end{array}$ \\
$854140(\mathrm{ex})$ & $\begin{array}{l}\text { Photosensitive semiconductor devices, including photovoltaic cells whether or } \\
\text { not assembled in modules or made up into panels; light emitting diodes. }\end{array}$ \\
\hline
\end{tabular}

The data show that exports have grown considerably from 1996 to 2008, whereas the largest growth occurred since 2002. Figure 1 supports the finding that the production of clean technology goods is highly skewed towards high income countries [5]. However, East Asian Pacific countries (LDCEAP), mainly China, have gained considerable market share. Interestingly, the data also show that the share of solar energy technology components in trade with industrial goods has been increasing since 1996. Although still low between 0,5 a nd $1,5 \%$ this indicates a quite dynamic market as the solar component trade growth rate has been larger than industrial goods trade growth rates. Another insight is that although the OECD countries are major exporters, the group runs an increasing net trade deficit hinting to the dominance of only some countries. An analysis of the trade direction between regions underlines that main import markets are in high income OECD countries with most of the trade occurring between OECD countries. Another important trade direction is from developing countries to developed counties. Trade between developing country regions remains marginal. Overall, it becomes obvious that the international market for solar energy 
technology components is dominated by Europe and China as the main exporting players. Europe furthermore is the dominating importer with most of the global trade occurring within Europe itself.
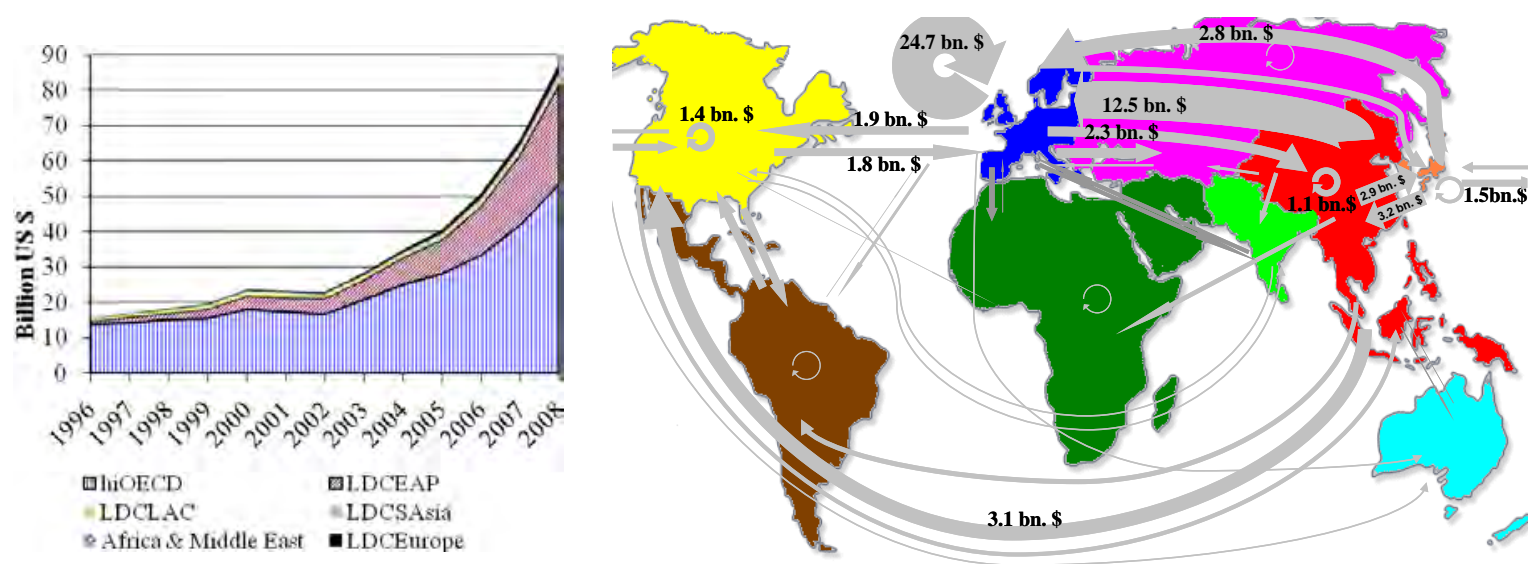

Figure 1. Development of Solar energy technology component exports by country group 1996-2008 and market structure 2008 (Source: UNCOMTRADE)

The analysis of country specific export flows and market shares underlines the dynamics and outlines the dominance of only some counties as well as the increasing importance of developing countries. Although, with a high increase in market volume the development of market export shares over time indicates a crowding out of some OECD exporters mainly due to strong export growth of China.

\subsubsection{General parameter of trade analysis}

The gravity model predicts that the bilateral trade volume is positively related to a countries' income $\left(G D P_{i t} G D P_{j t}\right)$ [6]. A counter force in this respect is population size as countries with a larger population $\left(P O P_{i t}, P O P_{j t}\right)$ are expected to trade less. The reason is that available resources and the domestic market size are expected to be positively correlated with the population size. The anticipated sign is thus negative as the market is able to rather produce goods itself. Theoretically, with increasing distance $\left(D I S T_{i j}\right)$, trade and transportation cost increase, reducing trade volume and causing the expected sign to be negative. Further determinants of bilateral trade flows that are empirically justified are included. Sharing an official language $(L A N G)$ and having a common border $\left(A D J_{i j}\right)$ is expected to increase bilateral trade flows as goods can be transported at lower costs. Data for these variables have been retrieved from the World Bank World Development Indicators (2009) and from the CEPII's Gravity Dataset (2010).

\subsubsection{The role of environmental regulation}

The empirical literature on the interaction between trade and environmental regulation remains ambiguous regarding the support of either the polluter haven or the Porter hypothesis [7]. According to the Porter hypothesis, shocks produced by new, stricter regulation creates external pressure on the firms which are subsequently fostered to created new products and processes that positively affect the dynamic behaviour of that economy and hence its international competitiveness. Thus, countries with a stringent environmental regulation may become net exporters of clean technology. The lead market literature, which supports the Porter hypothesis, indicates that an early introduction of adequate technology support policies can create an industry with a co mpetitive world market advantage. A contrary theoretical effect of introducing environmental regulation is that specific clean technology demand is 
generated causing additional imports as, in an open economy, foreign producers may provide technology either better or cheaper.

This studies' focus is on the effects of regulation on specific trade flows rather than on overall trade flows. Numerous policy instruments that increase the demand and supply of renewable energy technologies have been identified. The IEA report on 'Renewable energy market and policy trends' provides an overview of policies and time of introduction. Due to the heterogeneous character of these policies across countries the database does not facilitate an evaluation of regulatory stringency or renewable energy supportiveness in a panel context. Therefore, different measures of environmental stringency or renewable energy supportiveness, respectively, are used. In their study on export dynamics of energy technologies, Constantini and Crespil (2008) point out that an indirect measure of environmental stringency, such as $\mathrm{CO}_{2}$ emissions per unit of GDP is adequate to investigate the Porter hypothesis as well as the political importance of energy saving strategies [7]. The variables EnergInt ${ }_{i t}$ and EnvirREG $G_{i t}$ give the relative environmental strictness in exporting countries. The underlying assumption is that countries implementing stricter environmental regulation exhibit a positive effect on e xport dynamics of solar energy technology components. The measures are based on the following environmental indicators:

- Level of Energy intensity 1996 - 2008 in tons of oil equivalent per thousand units of purchasing power parity GDP extracted from the IEA Energy Balance database;

- Level of Carbon intensity 1996 - 2008 in $\mathrm{kg}$ per thousand units of purchasing power parity GDP extracted from the Carbon Dioxide Information Analysis Center database.

Subsequently, following the literature, sample countries have been ranked on these relative and dynamic measures $(1990=100)$ assigning the lowest rank to the worst performer. In the given panel structure this ranking method better allows for a comparison of relative environmental strictness than a comparison of levels of energy use and emissions.

The introduction of further variables controlling for environmental regulation and thus a renewable energy friendly policy environment is neglected. Although statistics suggest that the Kyoto Protocol induced more innovation there seems to be no significant effect of the Protocol on technology transfer and thus trade. ${ }^{5}$ In addition, other proxies of environmental regulation such as environmental private and public expenditures, environmental tax revenues and public environmental protection expenditures are likely to be captured by applied controls. The same is true for expected returns on energy investment, which is generally best reflected by electricity price trends. But, as total primary energy supply and therefore the energy market size of a country, is included in the estimation, incentives to invest in renewable energies are respected to some extent.

\subsubsection{The role of the innovation system in exporting countries}

In general, innovation is assumed to be a product of knowledge generating inputs [8]. As this study focuses on highly innovative technology goods, two variables controlling for the role of the innovation system in exporting countries are included.

First, a variable measuring a countries public technology specific research and development spending $\left(R D\right.$ Bsolar $\left._{i t}\right)$ is introduced. In theory, research and development increases exports as new technology might be developed which, in an open economy, is available to the world market as well. The variable enters the analysis lagged by one period assuming that the process of technology development takes some time until a new product is ready for market entry. Data is obtained from the IEA (2010) Energy Technology Research, Development and 
Demonstration database. The data show that combined OECD public spending on s olar energy has been constant since 1990 and is decreasing since 2006. Yet, there is substantial country level variation leaving the actual effect on export performance unclear.

Second, productivity of new knowledge is assumed to depend on the existing stock of ideas [8]. The patent stock of a country is the best proxy for knowledge stock in this respect. Therefore, patent counts for renewable energy have been extracted from the OECD (2010) Science, Technology and R\&D Statistics database. Aiming at comparability and an unbiased estimation, only patent applications by inventor country issued under the international patent cooperation treaty have been included (Figure 2).

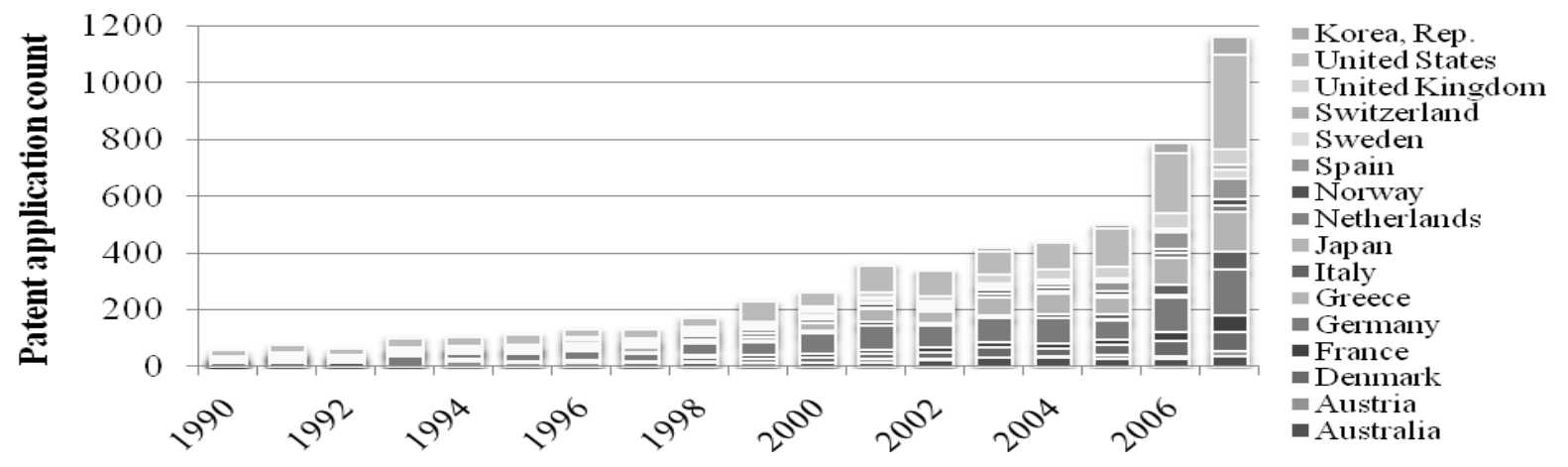

Figure 2: Renewable Energy Patent applications by country of origin 1990 - 2007

Based on the patent counts the countries' patent stock has been calculated with depreciation rate $\alpha$ of $15 \%$ as is commonly done in the literature ${ }^{8}$ :

$$
\text { PatStock }_{\text {it }}=(1-\alpha) \text { PatStock }_{\mathrm{it}-1}+\text { Patents }_{\text {it }}
$$

Naturally, the stock of knowledge with respect to renewable energies differs substantially between countries. Therefore, the assumption to be tested empirically is that countries with a higher renewable energy knowledge stock export more to the world market.

\subsubsection{The role of barriers to trade and regulation in importing countries}

A general assumption is that tariff and non-tariff barriers inhibit trade while a positive general policy environment as well as environmental friendly regulation in importing states supports cross border flows of the specific high technology goods which are the focus of this study. Hence, import tariffs (Import_Tariffj $i$ ) applied to the compounded product group of solar goods are introduced as an explanatory variable. Data on the effectively ad valorem tariff applied by the importing country $j$ to solar technology component exports from $i$ in percent of the import value is obtained from the UNCTAD TRAINS database. The indicator serves as control for the potential impact of a liberalization of environmental goods as discussed in the WTO Doha negotiations and denounces the reduction of additional trade cost over time. The expected coefficient sign is negative as bilateral trade flows are high with lower tariffs as exporters face reduced trade costs. The development of tariffs over time seems to support the theoretical underpinning. While solar energy technology component exports of OECD countries increased significantly, the mean tariff applied by the samples importing counties decreased substantially from $10 \%$ in 1996 to $5 \%$ in 2008 .

Environmental regulation and renewable supportiveness in receiving countries potentially plays a role as demand for clean technologies can be satisfied through the world market. 
Hence, the environmental stringency variable $\operatorname{EnergREG}_{j t}$ is introduced as control for such regulation using the same method as for exporting countries described above. The study also includes the World Bank's rule of law indicator $\left(R O L_{\mathrm{j}}\right)$ as a p roxy for the quality of institutions and the capacity to respect legal rules which might be relevant for exporters.

As currently the solar energy market development is often described in terms of investments, controlling for such investments to explain technology component export flows is necessary. Adequate solar technology specific investment data on a cross time cross country level is not yet available. Therefore, the best proxy in this respect is net foreign direct investment inflow in importing countries $\left(F D I_{j t}\right)$. Trade flows are tightly linked to foreign direct investments flows [9]. Following the literature on t rade flows and foreign direct investments the coefficient should be positive as a higher attractiveness of a county for FDI also exhibits a higher attractiveness for exports.

\section{Results}

The gravity model as stated in equation (2) has been estimated using random and fixed effects in order to control for country heterogeneity with robust standard errors clustered on country level. However, the significance of the Hausman test clearly indicates that exporting country individual effect $(\alpha)$ and the repressors are correlated. Thus, only the consistent fixed effect estimation coefficients on the repressors are reported in Table 2. Adequate tests for the robustness of the results have been conducted.

Table 2. Gravity model and the role of environmental regulation, innovation and trade parameters

\begin{tabular}{|c|c|c|c|c|c|c|c|c|}
\hline & $(1)$ & $(2)$ & (3) & (4) & $(5)$ & $(6)$ & $(7)$ & (8) \\
\hline $\ln \mathrm{GDP}_{\mathrm{ijt}}$ & $1,57^{\text {करक }}$ & $1,58^{\text {काल }}$ & $1,18^{\text {Tतन }}$ & $1,59^{\text {करत }}$ & $1,55^{\text {करn }}$ & $1,55^{\circ \pi}$ & $1,65^{\text {करn }}$ & $1,53^{\pi m \pi}$ \\
\hline $\ln \mathrm{POP}_{\mathrm{it}}$ & $-6,81^{*}$ & $-7,19^{*}$ & $-6,49^{*}$ & $-6,89^{*}$ & $-8,31^{*}$ & $-6,81$ & $-5,02$ & $-11,63^{* *}$ \\
\hline $\ln \mathrm{POP}_{\mathrm{jt}}$ & $-0,42^{* * *}$ & $-0,44^{* * *}$ & $-0,06$ & $-0,45^{* * *}$ & $-0,43^{* * *}$ & $-0,43^{* * *}$ & $-0,46^{* * *}$ & $-0,41^{* * *}$ \\
\hline $\ln \mathrm{DIST}_{\mathrm{ij}}$ & $-1,01^{* * *}$ & $-0,98^{* * *}$ & $-0,99^{* * * *}$ & $-1,00^{* * *}$ & $-1,01^{* * *}$ & $-1,00^{* * *}$ & $-0,99^{* * *}$ & $-0,93^{* * *}$ \\
\hline $\mathrm{ADJ}_{\mathrm{ij}}$ & 0,01 & 0,06 & $-0,05$ & $-0,01$ & 0,15 & 0,16 & $-0,22$ & 0,038 \\
\hline $\mathrm{LANG}_{\mathrm{ij}}$ & $1,15^{* * *}$ & $1,19^{* * *}$ & $1,01^{* * *}$ & $1,13^{* * *}$ & $1,11^{* * *}$ & $1,10^{* * *}$ & $1,19^{* * *}$ & $1,06^{* * *}$ \\
\hline \multicolumn{9}{|c|}{ Import Tariff $\mathrm{ijt}_{\mathrm{it}}-0,01^{* * *}$} \\
\hline $\ln \mathrm{FDI}_{\mathrm{jt}}$ & & $0,17^{* * *}$ & & & & & & \\
\hline $\operatorname{RoL}_{j \mathrm{t}}$ & & & $0,02^{* * *}$ & & & & & \\
\hline $\ln$ EnvirREG $_{\mathrm{jt}}$ & & & & $0,11^{*}$ & & & & \\
\hline $\ln$ EnergInt $_{\mathrm{it}}$ & & & & & $0,24^{*}$ & & & \\
\hline In EnvirREG ${ }_{i t}$ & & & & & & $0,15^{*}$ & & \\
\hline $\ln \mathrm{RDBsolar}_{\mathrm{it}-1}$ & & & & & & & $0,03^{*}$ & \\
\hline $\ln$ PatStock $_{\text {it }}$ & & & & & & & & 0,03 \\
\hline Time dummies & yes & yes & yes & yes & yes & yes & yes & yes \\
\hline $\mathrm{N}$ & 22382 & 21630 & 22550 & 22550 & 21793 & 19475 & 21263 & 36092 \\
\hline $\mathrm{R}^{2}$ & 0,68 & 0,69 & 0,70 & 0,68 & 0,67 & 0,67 & 0,70 & 0,64 \\
\hline
\end{tabular}

The results show that standard control coefficients of trade flow analysis such as income, population and distance have the expected impact. Thus, this set of controls is taken as basis for the analysis of the remaining control variables. These specific control variables also 
behave as expected. A one unit increase in tariffs decreases imports by 0.01 units. Thus, Higher tariffs significantly decrease import flows while the relationship between investment inflows and the institutional quality in receiving countries is positive. The impact of environmental regulation in importing countries on trade flows is weak but positive. The role of the innovation system in exporting countries remains ambiguous. On the one hand public spending in solar energy technology has a positive significant impact on export flows. On the other hand the renewable energy patent stock has no significant impact. The results of the study support the Porter Hypothesis as countries with a more stringent environmental regulation and a better energy intensive score export more solar energy technology components to the world market and thus seem to have gained a competitive advantage.

\section{Discussion and Conclusion}

This study applies an empirical gravity model to identify the main drivers of trade with solar energy technology components. Finding evidence for the Porter hypothesis and the importance of the innovations system the results are in line with findings of related work on environmental regulation and trade as well as with the OECD's strategy on environmental regulation, innovation and green growth. Yet, besides the issues related to a potential dual use of products under one HS-code the effects might be biased by the use of rather broad control variable specifications such as general renewable energy patents instead of solar specific patents to construct the knowledge stock. Nevertheless, the results are interesting from a global climate negotiation perspective as it is shown that the regulatory context in receiving countries is decisive for clean technology imports and thus potential technology transfer.

Consequently, the remaining research agenda should focus on technology transfer in trade with these clean energy technologies as well as the study of potential trade effects. Within this context the construction of regulation measures capturing renewable energy supportiveness of a country more directly should be developed.

\section{References}

[1] REN 21, 2009. Renewables Global Status Report: 2009 Update, 2009, Paris.

[2] Tinbergen, J., 1962. Shaping the World Economy, Twentieth Century Fund, New York.

[3] Jug, J.; Mirza, D., 2005. Environmental regulations in gravity equations: evidence from Europe, World Economics 28(11), pp.1591-1615.

[4] OECD, 1999. The environmental goods and services industry manual for data collection and analysis, Paris.

[5] Dechezleprêtre, A.; Hascic, I., 2008. Invention and Transfer of Climate Change Technology on a Global Scale: A Study Drawing on Panel Data, Paris, 2008.

[6] Harris, M.; et al., 2002. Modeling the Impact of Environmental Regulation on Bilateral Trade Flows: OECD, 1990 -1996, in: The World Economy, vol.25 (3), 2002, pp.387-407.

[7] Constantini, V.; Crespi, F., 2008. Environmental regulation and the export dynamics of energy technologies, in: Ecological Economics 66(2008), pp. 447-460.

[8] Braun, F.; et.al., 2010. Innovative Activity in wind and solar technology: empirical evidence on knowledge spillovers using patent data, DIW Discussion Paper XI992/2010, Berlin.

[9] Makki, S., 2007. Impact of Foreign Direct Investment and Trade on Economic Growth, Washington. 